Research Article

\title{
Genotypic diversity of the Killer Cell Immunoglobulin-like Receptors (KIR) and their HLA class I Ligands in a Saudi population
}

Suliman Y. Al Omar ${ }^{1}$, Afrah Alkuriji ${ }^{1}$, Saleh Alwasel, javid Ahmed Dar ${ }^{2}$, Alwaleed Alhammad ${ }^{3}$, Stephen Christmas ${ }^{4}$ and Lamjed Mansour ${ }^{1,5}$

${ }^{1}$ Zoology Department, College of Science, King Saud University, Riyad, Saudi Arabia.

${ }^{2}$ Central Laboratory College of Science, King Saud University, Riyad, Saudi Arabia.

${ }^{3}$ Immunology Unit, Department of Pathology, King Saud University, Riyad, Saudi Arabia.

${ }^{4}$ Department of Clinical Infection, Microbiology \& Immunology, Institute of Global Health, Faculty of

Health \& Life Sciences, University of Liverpool, Liverpool, UK.

${ }^{5}$ Unité de Recherche de Biologie Intégrative et Ecologie Évolutive et Fonctionnelle des Milieux Aquatiques,

Département de Biologie, Faculté des Sciences de Tunis, Université de Tunis El Manar, Tunisia.

\begin{abstract}
Killer Cell Immunoglobulin-like Receptors (KIR) have been used as good markers for the study of genetic predisposition in many diseases and in human genetic population dynamics. In this context, we have investigated the genetic diversity of KIR genes and their main HLA class I ligands in Saudi population and compared the data with other studies of neighboring populations. One hundred and fourteen randomly selected healthy Saudi subjects were genotyped for the presence or absence of $16 \mathrm{KIR}$ genes and their HLA-C1, $-\mathrm{C} 2,-B w 4^{\text {Thro }}$ and Bw4 $4^{1 \mathrm{les}}$ groups, using a PCR-SSP technique. The results show the occurrence of the framework genes (3DL2, 3DL3 and 2DL4) and the pseudogenes (2DP1 and 3DP1) at highest frequencies. All inhibitory KIR (KIR) genes appeared at higher frequencies than activating genes (aKIR), except for 2DS4 with a frequency of $90.35 \%$. A total of 55 different genotypes were observed appearing at different frequencies, where 12 are considered novel. Two haplotypes were characterized, $A A$ and $B x$ (BB and $A B$ ), which were observed in $24.5 \%$ and $75.5 \%$ respectively of the studied group. The frequencies of $\mathbb{K I R}+\mathrm{HLA}$ associations were found to be much higher than aKIR + HLA. KIR genes frequencies in the Saudi population are comparable with other Middle Eastern and North African populations.
\end{abstract}

Keywords: KIR diversity; gene polymorphism; molecular evolution; PCR SSP; population viability analysis.

Received: February 24, 2015; Accepted: August 04, 2015.

\section{Introduction}

Natural killer (NK) cells are considered the first line of defense of the innate immune response against both infected and malignantly transformed cells. They act through their cytotoxic activity or by the production of a panel of cytokines. These activities are accomplished by two subpopulations; CD56 ${ }^{\mathrm{dim}}$ cells, mainly responsible for cytotoxic activity and CD56 ${ }^{\text {bright }}$ cells, having a role as cytokine producer cells (Caligiuri et al., 1989, Cooper et al., 2001). The killing activity of NK cells is regulated through a range of receptors belonging to different families. One common family of receptors are called killer cell immunoglobulin-like receptors (KIR) expressed by natural killer cells and a subset of $\mathrm{T}$ cells, are glycoproteins playing an important role in innate cytotoxic activity. Through their interac-

Send correspondence Lamjed Mansour. Department of Zoology, College of Science, King Saud University PO. Box: 2455, Riyadh, 11451, Saudi Arabia. E-mail address:lamjed.mansour@gmail.com tions with Human Leukocyte Antigens (HLA)-I and other ligands, they regulate the cytotoxic activity of the NK cells, by balancing the function of these cells between activating and inhibitory signals (Vilches and Parham, 2002, Parham, 2005, Parham and Moffett, 2013). The KIR genes form a cluster on chromosome 19q13.4 within the Leukocyte Receptor Complex (LRC) in a region spanning approximately $1 \mathrm{Mb}$ (Wagtmann et al., 1997, Torkar et al., 1998). These KIR genes are characterized by their allelic and haplotypic polymorphisms which were associated with the resistance vs. susceptibility to many diseases, such as infections, cancers and autoimmunity (Kulkarni et al., 2008a, Al Omar et al., 2010, Hou et al., 2010, Jiao et al., 2010, Garcia-Leon et al., 2011, Augusto et al., 2012, Ivarsson et al., 2013, Jarduli et al., 2013, Chavan et al., 2014).

The KIR gene cluster is composed of 16 genes coding for activating or inhibitory receptors and two pseudogenes (Marsh et al., 2003a). KIR gene nomenclature as defined by the World Health Organization subcommittee was based on 
the structure of the encoded molecules. Thus according to the number of extracellular immunoglobulin domains (D) which may be double (2D) or triple (3D) and the length of the intracytoplasmic tail that would be long (L) or short (S), the KIR genes have been named and classified as inhibitory (with long cytoplasmic tail) or activating genes (having short cytoplasmic tail) (Long et al., 1996). Actually eight genes were reported coding inhibitory molecules named (KIR2DL1， KIR2DL2, KIR2DL3, KIR2DL5A, KIR2DL5B, KIR3DL1, KIR3DL2 and KIR3DL3) and seven genes for the activating molecules (KIR2DS1, KIR2DS2, KIR2DS3, KIR2DS4, KIR2DS5A/B and KIR3DS1). The gene KIR2DL4 appeared to have both functions (Faure and Long, 2002). KIR2DP1 and KIR3DP1 are pseudogenes (Wilson et al., 2000, Marsh et al., 2003b). Genetic variability in KIR between individuals results from allelic diversity for some genes and the composition of haplotypes (presence or absence of some genes) leading to different genotype composition. Currently, more than 500 different genotypes have been described (Gonzalez-Galarza et al., 2014). Four genes KIR2DL4, KIR3DL2, KIR3DL3 and KIR3DP1 considered as 'framework' are present in nearly all individuals, and for the other genotypes different combinations of genes lead to different haplotypes. Despite the number of the generated haplotypes, two distinct groups were defined, termed $\mathrm{A}$ and $\mathrm{B}$, based upon gene content. Group B haplotypes were defined by the presence of at least one the following genes: KIR2DS1/2/3/5, KIR3DS1and KIR2DL5. Conversely, in group A haplotypes all these genes are missing (Uhrberg et al., 2002).

It is now accepted that the killing function of NK cells depends on the composition of activating and inhibitory receptors present on the membrane and the interaction with their HLA ligands. Specificity towards HLA-A, -B, -C and -G ligands has been demonstrated for some KIR molecules (Brooks et al., 2000, Moretta et al., 2014). For HLA-C, based on the amino acid at position 80 in the heavy chain, two groups of ligands were reported. In the HLA-C1 group, position 80 is occupied by the amino acid lysine, while in the HLA-C2 group the amino acid at the same position is asparagine (Moretta et al., 1995). The discrimination between the two groups of HLA-C is allowed by position 44 in the D1 domain of KIR. The inhibitory KIR2DL2/3 and the activating KIR2DS2 bind to the HLA-C1 ligand while KIR2DL1 and KIR2DS1 bind to HLA-C2 (Du et al., 2007). The inhibitory signal triggered by the KIR2DL2/3 + HLA$\mathrm{C} 1$ interaction is relatively weaker as compared with that triggered by the KIR2DL1 + HLA-C2 interaction (Mandelboim et al., 1996, Moesta et al., 2008). The ligand of the receptors KIR3DL1/S1 is the HLA-B allotypes and certain HLA-A molecules that express the Bw4 epitope, serologically defined having a determined motif at amino acid position 77-83 (Cella et al., 1994, Gumperz et al., 1995). According to the amino acid at position 80 of HLA-B having the Bw4 epitope, a dimorphic molecule is expressed;
Bw4 Isoleucine and Bw4 Threonine, which affects the strength of interaction with the KIR3DL1 receptor. The inhibitory signal triggered with HLA-B Bw $4^{\text {Ile } 80}$ is generally stronger than the one triggered with HLA-B Bw4 ${ }^{\text {Thr80 }}$ (Gumperz et al., 1997, Carr et al., 2005). Other KIR-HLA interactions were reported for KIR3DL2 which binds HLA-A3 and HLA-A11, while the association KIR2DL4 HLA-G remains controversial (Long and Rajagopalan, 2000, Hansasuta et al., 2004, Rajagopalan and Long, 2005, O'Connor et al., 2007).

The activating receptor KIR2DS1 has been shown to bind weakly to HLA-C2 while KIR2DS2 binds weakly to HLA-C1 (Stewart et al., 2005, Chewning et al., 2007, Foley et al., 2008).

The aim of this work is to contribute to the assessment of the pattern of genetic diversity in 114 healthy Saudi subjects based on the genetic polymorphism of the KIR genes. Our results were used for comparative analysis with other published data for Saudis and neighboring populations. Moreover, the main HLA class I ligands were also typed in order to evaluate the killing function efficiency of the NK cells.

\section{Materials and Methods}

\section{Study group}

Blood samples were obtained from 114 unrelated healthy individuals selected randomly from the Saudi population visiting the King Khaled University Hospital (KKUH), Riyadh, Kingdom of Saudi Arabia. All participants were asked for their consent according to the permit issued by the Ethics Committee of King Saud University for this study. Among this healthy group, 65 were women and 49 men. Genomic DNA was prepared using the DNeasy Blood \& Tissue Kit (Qiagen, Valencia, CA, USA).

\section{KIR and HLA ligands genotyping}

KIR genotyping was performed by PCR-SSP for the presence or absence of the $14 \mathrm{KIR}$ genes, (KIR2DL1, 2DL2, $2 D L 3,2 D L 4,2 D L 5,2 D S 1,2 D S 2,2 D S 3,2 D S 4,2 D S 5$, $3 D L 1,3 D L 2,3 D L 3,3 D S 1)$ and the two pseudogenes $(3 D P 1$ and $2 D P 1)$. Genotyping was firstly performed by the commercially KIR typing kit (Miltenyi Biotec, Inc, Germany) according to the manufacturer's recommendations and the results were confirmed by an alternative protocol using a set of primers previously reported by Vilches et al. (2007).

For HLA-C1, HLA-C2 and HLA-B Bw4 group typing, the same primers reported by Tajik et al. (2010) were used. For each assay, PCR was performed in a $20 \mu \mathrm{L}$ final volume containing $4 \mu \mathrm{L}$ of $5 \mathrm{x}$ FIREPol ${ }^{\circledR}$ Master Mix ready-to-use (Solis Biodyne, Estonia), 0.2 pmol of each primer, 50-100 ng of DNA and ultra-pure water (MilliQ). In addition, for each amplification reaction an internal control of the growth hormone gene was amplified using the 
primers hGH forward (5'-GCCTTCCCAACCATTCCCT TA-3') and hGH reverse, (5'-GTCCATGTCCTTCCTGA AGCA-3') (Tajik et al., 2009, 2010). The PCR cycling protocol used consisted of an initial step of denaturation at $94^{\circ} \mathrm{C}$ followed by 5 cycles of $20 \mathrm{~s}$ at $94^{\circ} \mathrm{C}, 30 \mathrm{~s}$ at $64^{\circ} \mathrm{C}$ and $60 \mathrm{~s}$ at $72^{\circ} \mathrm{C}, 25$ cycles of $94^{\circ} \mathrm{C}$ for $30 \mathrm{~s}, 60^{\circ} \mathrm{C}$ for $30 \mathrm{~s}$, and $72^{\circ} \mathrm{C}$ for $90 \mathrm{~s} ; 5$ cycles of $94 \mathrm{C}^{\circ}$ for $30 \mathrm{~s}, 55^{\circ} \mathrm{C}$ for $30 \mathrm{~min}$, and $72^{\circ} \mathrm{C}$ for $90 \mathrm{~s}$, followed by a final extension step for 10 min at $72^{\circ} \mathrm{C}$. All PCR assays were performed with the Techne TC-Plus Satellites (Bibby Scientific, Staffordshire, UK) thermocycler apparatus.

The PCR products were analyzed by electrophoresis in $2 \%$ agarose gel stained with ethidium bromide and visualized on an UV transilluminator using a gel documentation system (Gel225 DocXR BioRad) to check the presence or absence of gene-specific amplicons.

\section{Statistical analysis.}

The frequencies of the KIR genes and KIR AA and $\mathrm{BX}$ genotypes, as well as their ligands HLA-C1 and -C2 groups and HLA-B Bw4 were established by direct counting. The significance of differences of KIR gene proportions between our sampled populations and other selected ones were estimated using the two-tailed Fisher's exact test with SigmaPlot software version 11. P values of $<0.05$ were considered to confirm significance of differences. All values in the studied groups were in Hardy-Weinberg equilibrium. Principal component analysis (PCA) and estima- tion of the Euclidean distances were performed with Primer E-6 Package (Clarke, 1993) to minimize the genetic distances between our population and other selected ones.

\section{Results and Discussion}

The aim of this work was to assess the KIR gene diversity in a Saudi group of 114 randomly selected healthy unrelated individuals. For this purpose, we used two protocols based on the Sequence-Specific Primer-directed Polymerase Chain Reaction (SSP-PCR). All samples were typed with a commercially KIR typing kit (Miltenyi Biotec, Inc) using unknown primers and a protocol based on the primers designed by Vilches et al. (2007). Both protocols gave $100 \%$ concordant results. The distribution frequencies of the 16 KIR genes and their HLA class I ligands in a randomly selected 114 healthy unrelated Saudi group are reported in Figure 1.

The framework genes KIR $3 D L 2,-D L 3$ and $-3 D P 1$ appeared in $99.1 \%(113 / 114)$ of the subjects. The framework gene $2 D L 4$ was observed in $97.4 \%$ (111/144). The inhibitory genes $2 D L 1,2 D L 3,3 D L 1$ appeared with relatively high frequencies $(>80 \%)$ and only $2 D L 2$ and $2 D L 5$ were observed with the same frequency at $58.8 \%$. The second pseudogene $2 D P 1$ had the same frequency as $3 D P 1$.

Comparisons of these frequencies with those of 12 other studied populations including two Saudi groups were made (Tables 1 and 2). We noticed that while the percent-

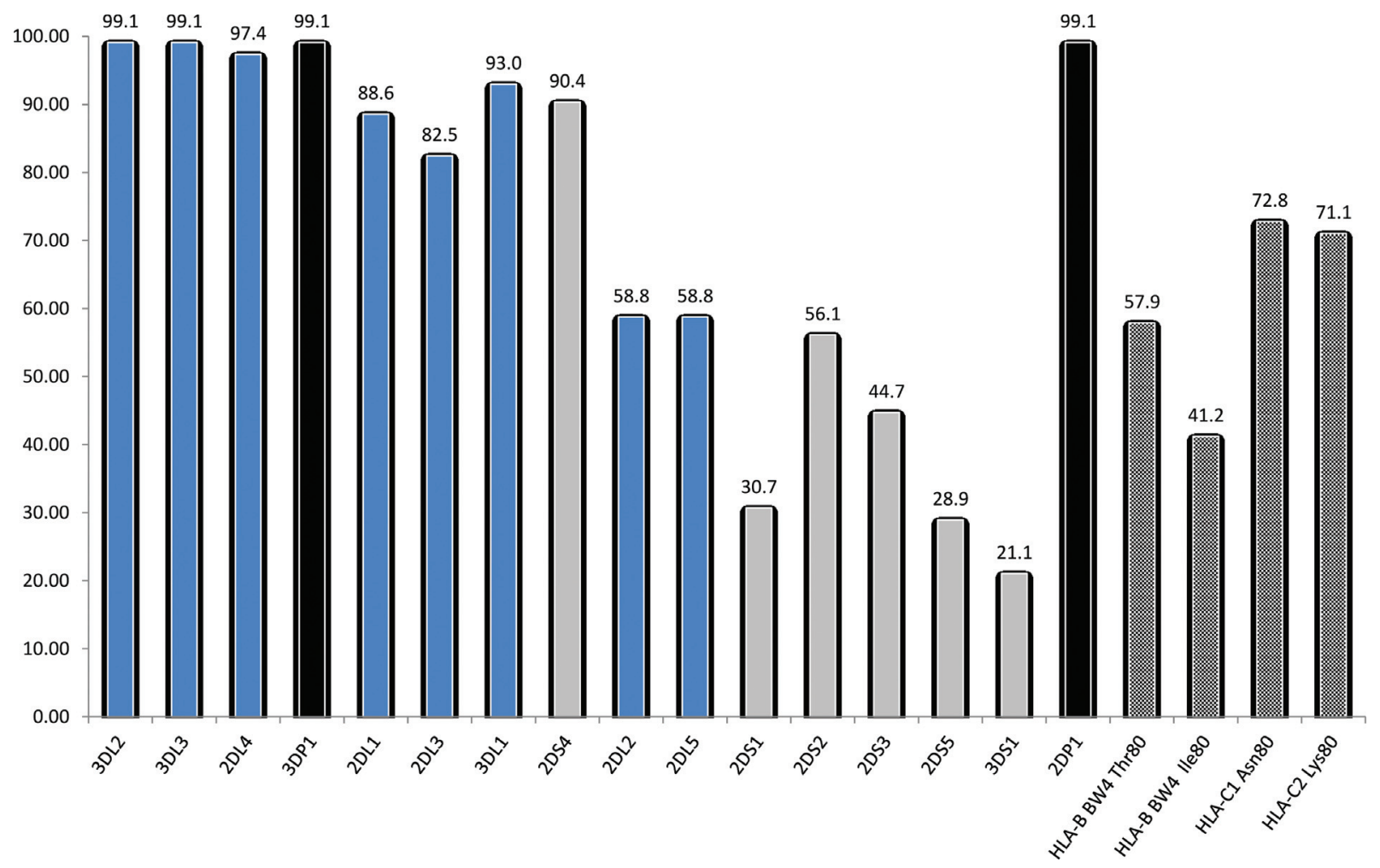

Figure 1 - Distribution of observed frequencies of KIR genes and their HLA ligands among the studied Saudi population. Blue $=$ inhibitory, grey $=$ activating, black $=$ pseudogenes, hatched $=$ HLA ligands . 


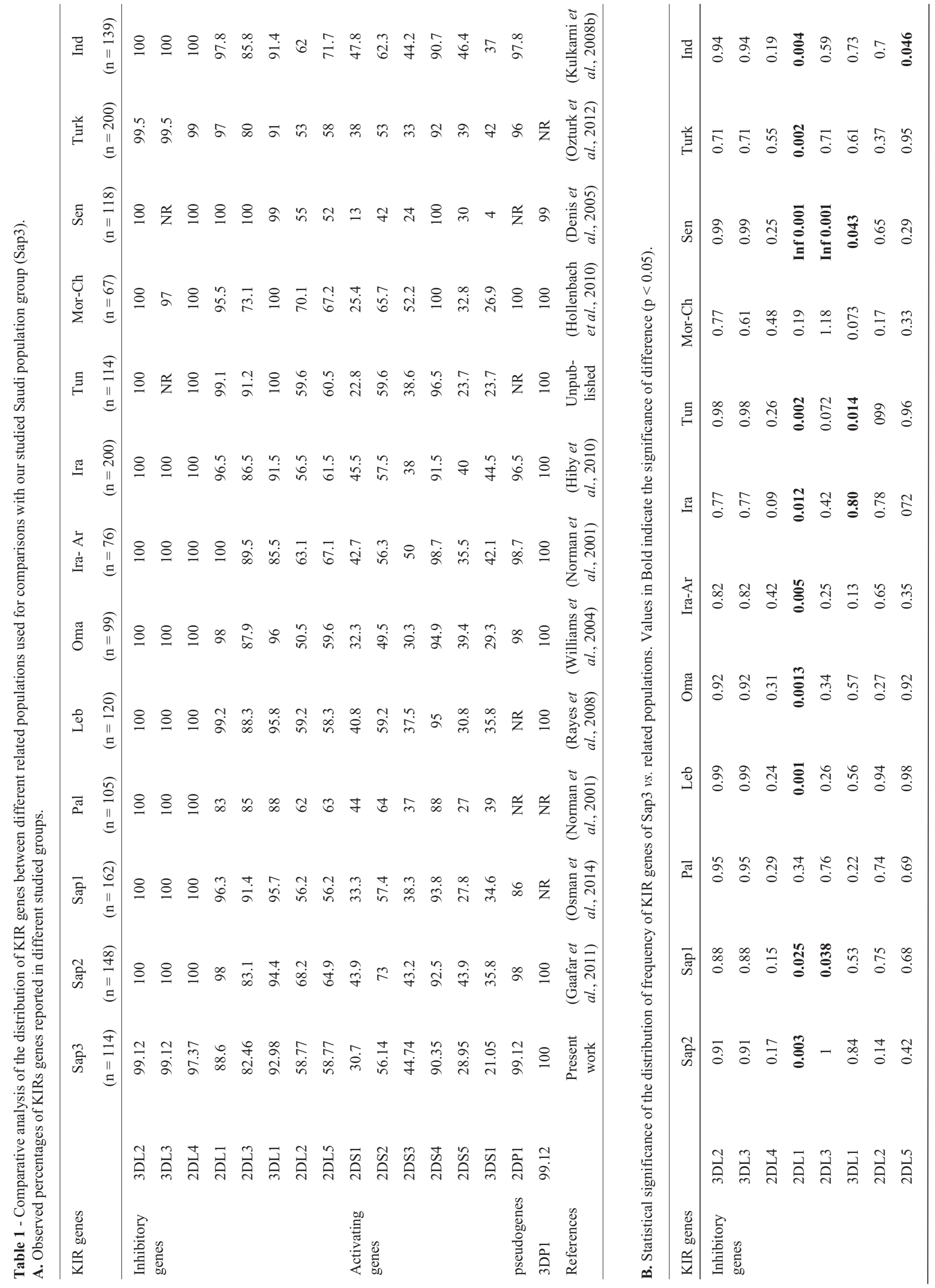




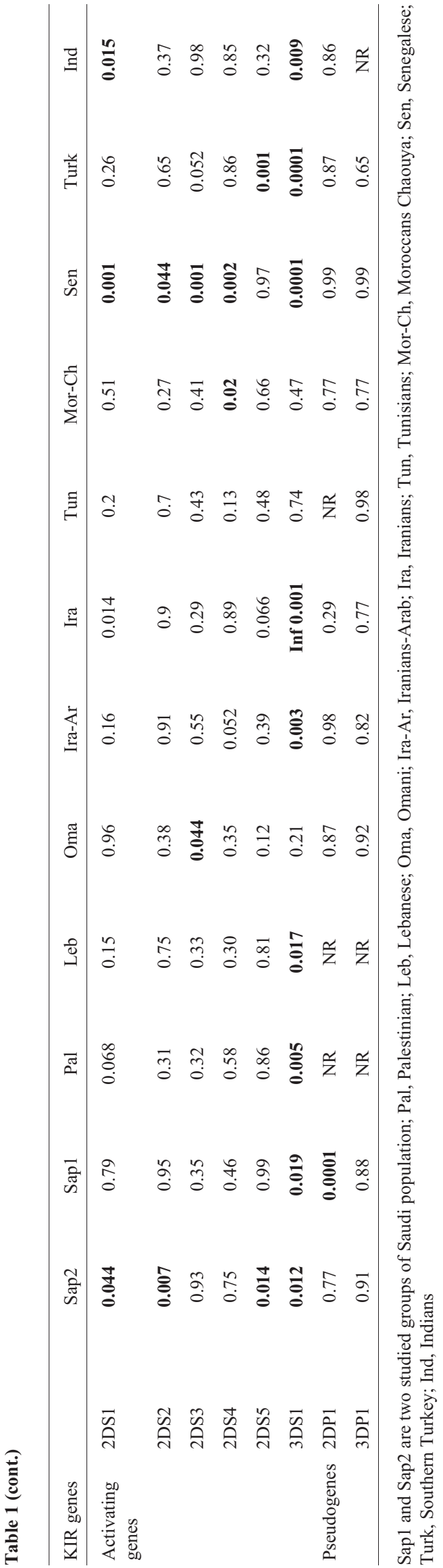

ages of the framework genes did not reach $100 \%$, they are in the range of all reported studies $(\mathrm{P}<0.05)$. For both studied Saudi groups, these percentages were $100 \%$ for all framework genes (Gaafar et al., 2011, Osman et al., 2014). For these genes, only the percentages in a group from Southern Turkey reported by Ozturk et al. (2012) are less than $100 \%$. These framework genes were lacking in three individuals. Two individuals were A haplotypes and lacking two framework genes simultaneously $(3 D L 3,2 D L 4$ and $3 D L 2,2 D L 4)$. These individuals would be homozygote for the Kir haplotypes and could carry a large deletion spanning these loci, probably as a consequence of unequal crossing over events. However, errors caused by limitations in the techniques cannot be excluded. Sequencing of these unusual two individuals should confirm this information. Double deletion of the framework genes were also reported in other studies, such as of the admixed population of Belem, in the Northern region of Brazil and in a Swedish study group (Martin et al., 2008, Pedroza et al., 2011, Gonzalez-Galarza et al., 2014).

The frequency of $2 D L 1$ here reported is significantly different to almost all studied populations except the Palestinians and the Moroccan Chaouya groups. The highest frequency $(100 \%)$ of this gene occurs in Senegalese, IranianArab and Indian groups. Thus, only the Palestinian and the Moroccan Chaouya groups have no significant differences in the distribution of frequencies of inhibitory genes. Our Saudi group has only one significant difference in the frequencies of $i$ KIR genes with Saudi S2 group, Lebanese, Omani, Iranian-Arab, and Turkish groups and two significant differences with Saudi S1, Tunisian, Iranian and Indian groups. The most divergent was the Senegalese population with three significant differences in $2 D L 1,2 D L 3$ and $3 D L 1$ genes.

For the activating genes only the Tunisian group showed no significant differences in the frequencies of $a$ KIRs with our studied group. One significant difference was observed with Saudi S1, Palestinians, Lebanese, Omani, Iranians-Arab, Iranian and Moroccan Chaouya. The Saudi S2 has four significant differences with our group. The Senegalese group remains the most divergent with five significant differences. And finally, in the distribution of the pseudo-genes, only the 2DP1 in Saudi S1 appears lower than all the reported populations.

Based on the presence or absence of inhibitory and activating KIR gene content, two major haplotype groups A and B were considered. The homozygote AA haplotype is defined by the absence of all the following genes, KIR2DL2, -2DL5, -2DS1, -2DS2, -2DS3-2DS5 and -3DS1. Conversely, individuals carrying at least one of these genes are considered $\mathrm{Bx}$ genotype grouping $\mathrm{AB}$ and $\mathrm{BB}$ haplotypes.

Identification of KIR genes among the studied Saudi group showed the occurrence of 55 different genotypes (Figure 2). These genotypes were characterized by refer- 
Table 2 - Statistical comparisons of AA /Bx genotypes between our population SaP3 and some related populations. Values in bold for $\mathrm{p}<0.05$.

\begin{tabular}{|c|c|c|c|c|c|c|c|c|c|c|c|c|c|c|}
\hline Populations & & Sap3 & Sap2 & Sap1 & Pal & Leb & Oma & Ira- Ar & Ira & Tun & Mor-Ch & Sen & Turk & Ind \\
\hline Genotypes & $\mathrm{AA}$ & 24.5 & 18.2 & 26.5 & 22.9 & 26.7 & 29.3 & 15.7 & 27.5 & 29.8 & 16.4 & 53 & 29 & 23.7 \\
\hline$\%$ & $\mathrm{Bx}$ & 75.5 & 81.8 & 72.9 & 77.1 & 73.3 & 70.7 & 83.3 & 72.5 & 70.2 & 83.5 & 47 & 71 & 76 \\
\hline $\mathrm{p}$ & $\mathrm{AA} / \mathrm{Bx}$ & - & 0.28 & 0.76 & 0.91 & 0.80 & 0.51 & 0.23 & 0.33 & 0.43 & 0.28 & $<0.001$ & 0.44 & 0.98 \\
\hline
\end{tabular}

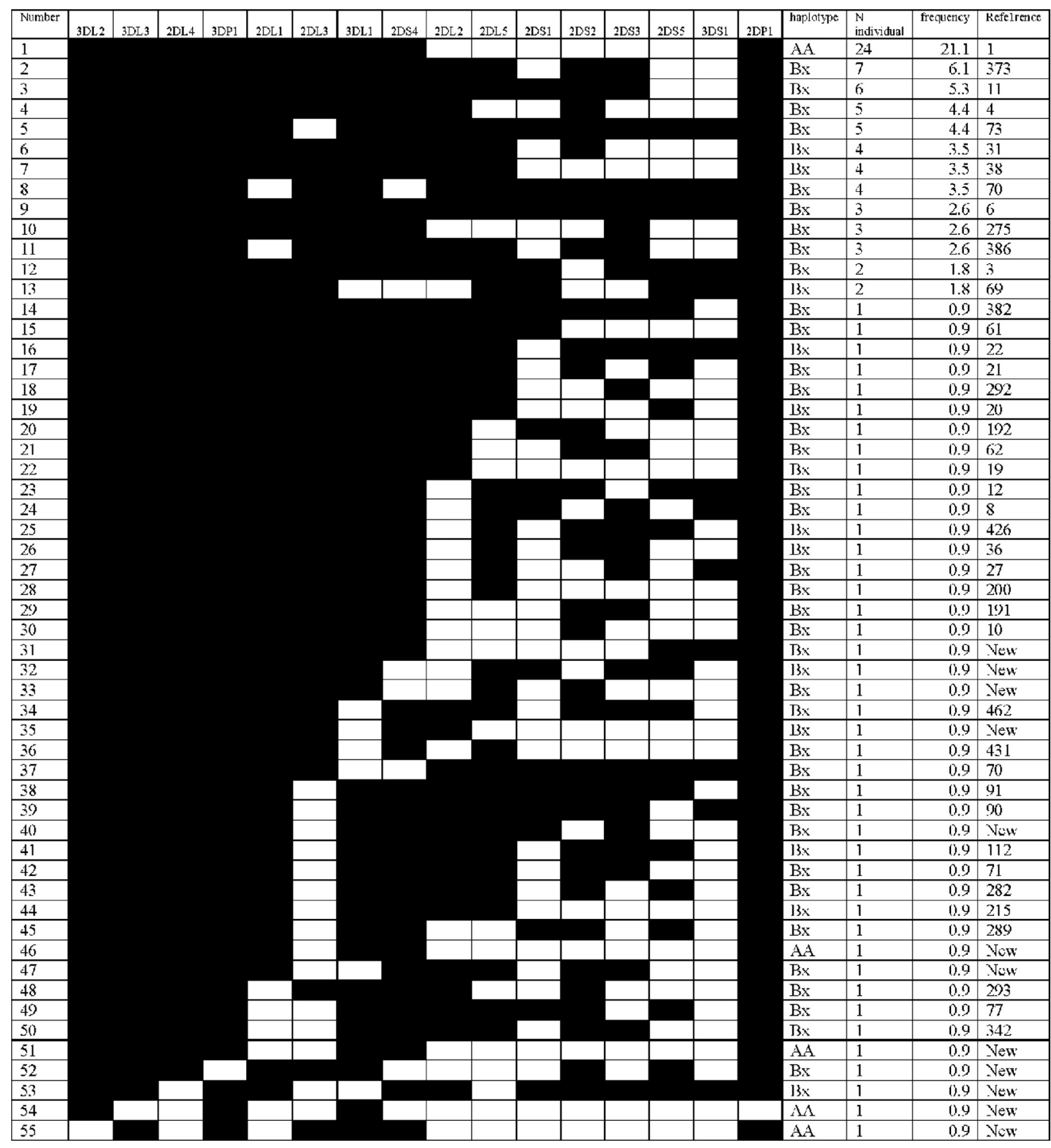

Figure 2 - Characterization and distribution of KIR genotypes observed in 114 Saudis individuals. Presence and absence of genes are indicated by filled and open rectangles, respectively.

ring to the allele frequencies database (http://www.allelefrequencies.net) (Gonzalez-Galarza et al., 2014). Among the 55 genotypes identified 12 of them were new. Thirteen genotypes have frequencies $>1 \%$ and they represent $63 \%$ of the studied groups. The homozygote AA referenced as haplotype number 1 is the most frequent 
with $21.1 \%$. This is the case for the two last reported Saudi groups (Sap1 and Sap2) and most other studied populations. Comparison made with the twelve selected groups, showed a significant difference in the frequency of haplotypes AA and BB only with the Senegalese study group ( $\mathrm{p}<$ 0.001 ) (Table 2). In this African population we noted a frequency of the AA haplotype higher than $\mathrm{Bx}(42 \%$ vs. $38 \%)$. We noted the presence of the reference genotype number 6 with only $2.6 \%$, which was reported at $8.8 \%$ in Sap1 and $8.7 \%$ in Sap2. The number of genotypes in common with Sap1 and Sap2 were 11 and 12 respectively. We recall that in these two Saudi groups 41 genotypes were reported in the Sap 1 and 31 genotypes in the Sap2. Only five genotypes were common to the three subpopulations which are the references 1, 4, 6, 70 and 112. Thus, for a total of 127 genotypes observed in these Saudi groups, only 23 were observed in at least two groups, the remaining 104 genotypes were reported individually. This data suggest a high heterogeneity and diversity in the Saudi population.

Knowing the importance of some HLA ligands in the interactions with the KIR receptors, we have also studied the distribution of the frequencies of HLA-C1 and $\mathrm{C} 2$ and HLA Bw4 in this Saudi group (Figure 1). HLA-C1 and -C2 groups appeared with similar frequencies (72.8 and $71.05 \%$ respectively). HLA-B Bw4 occurred in $73.7 \%$ of the subjects. The groups HLA-B Bw $4{ }^{\text {Thr } 80}$ and HLA-Bw $4{ }^{\text {Ile } 80}$ were observed in $57.9 \%$ and $41.2 \%$ respectively of the typed individuals.

Table 3 shows the different genotypes of HLA KIR ligands observed in the study population. Six genotypes were observed. The most frequent was $\mathrm{Bw} 4+\mathrm{C} 1+\mathrm{C} 2$ carried by $29.8 \%$ individuals. Those carrying two different ligands were more frequent than those with only one ligand (Table 3). These results corroborate with those reported in the Iranian population (Tajik et al., 2010).

Analysis of different combinations between KIR genes and their supposed HLA ligands are presented in Table 4 . We note that for the $i \mathrm{KIR}$, the frequency of the individual sharing $2 D L 2 / 3-\mathrm{C} 1$ appeared with the highest frequency. 2DL1-C2 and 3DL1-Bw4 were relatively high and had the same percentage. Conversely, the distribution of $a$ KIR-HLA ligand is variable (Table 4). For the HLA-C1

Table 3 - Different associations of HLA KIR ligands among the studied Saudi population

\begin{tabular}{lccccc}
\hline Ligands & C1 & C2 & B Bw4 & number & $\%$ \\
\hline C1/C2/B & + & + & + & 34 & 29.82 \\
Bw4 & & & & & \\
C1/C2 & + & + & & 15 & 14.03 \\
C1/B Bw4 & & + & + & 27 & 23.68 \\
C2/B Bw4 & + & & + & 23 & 20.17 \\
C1 & + & & & 6 & 5.26 \\
C2 & & + & & 8 & 7.01 \\
\hline
\end{tabular}

Table 4 - Distribution of $i$ KIR and $a$ KIR and their HLA ligands

\begin{tabular}{ccc}
\hline & KIR + HLA & $\%$ of individuals \\
\hline iKIR + HLA & 2DL2/3 + C1 & 73.68 \\
2DL1 + C2 & 66.67 \\
3DL1+ Bw4 & 66.67 \\
aKIR + HLA & 3DL1 +B Bw4 Ile80 & 37.71 \\
3DL1 + B Bw4 Thr80 & 50.87 \\
2DS2 + C1 & 42.09 \\
2DS1 + C2 & 20.17 \\
3DS1 + Bw4 & 19.2 \\
& 3DS1 +B Bw4 Ile80 & 8.8 \\
& 3DS1 +B Bw4 Thr80 & 17.5 \\
\hline
\end{tabular}

ligand, it was observed associated with $2 D L 2 / 3$ in $73.68 \%$ of the subjects against $42.09 \%$ for the $2 D S 2$. The genotype $2 D L 2 / 3,2 D S 2, C 1$ was observed in $28.9 \%$. The percentage of $2 D L 2 / 3$ positive individuals without $\mathrm{C} 1$ was $27.27 \% v s$. $13.15 \%$ for $2 D S 2$.

The ligand HLA-C2 had a frequency of $71 \%$. Its association with $K I R 2 D L 1$ gave a stronger signal than the association $2 D L 2 / 3-\mathrm{C} 1$. The association $2 D L 1-\mathrm{C} 2$ was observed with a frequency of $66.67 \% v s .20 .17 \%$ for the association of this ligand with the activating KIR $2 D S 1$. The genotype $2 D L 1-2 D S 1$ was observed in $24.7 \%$ of individuals. Their simultaneous association with $\mathrm{C} 2$ ligand was observed in $18.4 \%$ cases only. $21.9 \%$ of the $2 D L 1+$ and $34.3 \%$ of the $2 D S 1+$ groups were $\mathrm{C} 2$ free.

HLA-B Bw4 occurred in $73.68 \%$ of the study group. $66.6 \%$ are $3 D L 1-\mathrm{Bw} 4+v$ s. $19.2 .3 \%$ for the genotype $3 D S 1-B w 4$. The genotype $3 D L 1,3 D S 1$, Bw4 was observed in $16.6 \%$ of cases. We have observed $27.3 \%$ of $3 D L 1$ and $4.6 \%$ of $3 D S 1$ individuals without the B Bw4 ligand.

A principal component analysis mapping of the 12 selected populations based on the frequencies of $12 \mathrm{KIR}$ genes is represented in Figure 3. The results show that our Saudi population Sap3 clusters well with other Asiatic and North African populations. The Senegalese population appears quite divergent and is located away from all other groups. It is worth mentioning that Sap3 is genetically closely related to the Tunisian population. The Sap1 group occurs in a same cluster with the Turkish, Lebanese and Omani population. However, the Iranians-Arab population shows some genetic distance from the Sap2 sample.

These results corroborate with other paleoanthropic and genetic studies showing the common origin of the Saudis and other population belonging either to the Arabian Peninsula, Levant, African populations and other Asiatic ethnics groups (Abu-Amero et al., 2007, Abu-Amero et al., 2008, Cadenas et al., 2008, Abu-Amero et al., 2009, AbuAmero et al., 2011, Rosa and Brehem, 2011, Soares et al., 2012, Abu-Amero et al., 2013, Alsmadi et al., 2013). In fact, according to the 'out of Africa theory' model, Saudi Arabia is thought to have played a key role in the dispersion 


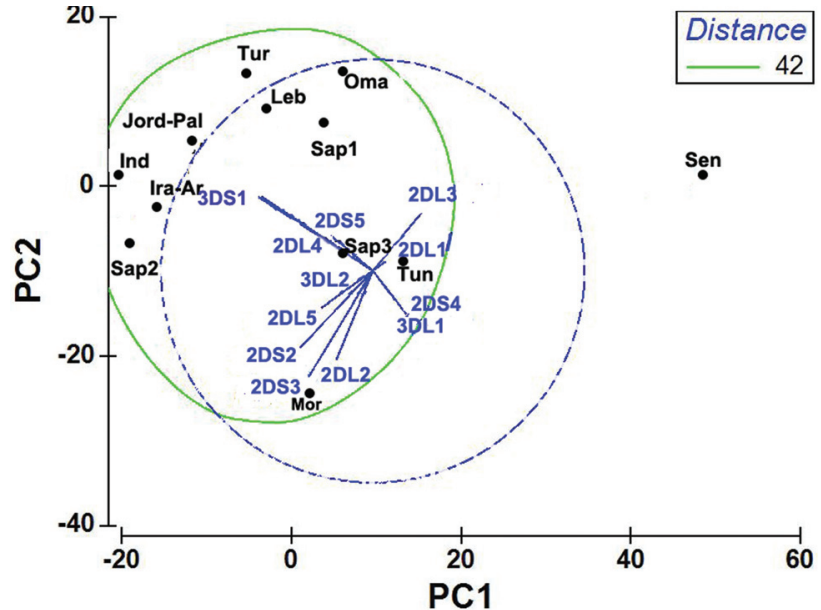

Figure 3 - Spatial distribution along the first and second principal components (PC1 and PC2) grouping 74.2 of the variance of 12 KIR genes frequencies from our studied Saudi population (Sap3) and 11 other previously described populations). The relative contribution of each KIR gene to variability is represented by blue arrows. Circles indicate two different clusters obtained for two Euclidean distances (21 for the circle in blue and 42 for the circle in green). For an Euclidean distance 42, only the Senegalese population is out of the cluster.

of early human populations outside of Africa, mainly through the Sinai Peninsula and Bab-el-Mandeb routes probably since the last glacial period. Later, these people continued to spread to the Near East through the Levantine corridor (Petraglia, 2003, Alsmadi et al., 2013).

Through the KIR data analysis we confirmed that the Saudi Arabia population has mainly been a recipient of gene flow from the surrounding areas in Asia and Africa. Explorations KIR diversity of other admixed and unique populations of the Arabian Peninsula is very interesting and can provide more information about the evolutionary history and the dynamic of this ethnic group.

\section{Acknowledgments}

This project was supported by the NSTIP strategic technologies program (number 11MED1900-02) of the Kingdom of Saudi Arabia.

\section{References}

Abu-Amero KK, Cabrera VM, Larruga JM, Osman EA, Gonzalez AM and Al-Obeidan SA (2011) Eurasian and Sub-Saharan African mitochondrial DNA haplogroup influences pseudoexfoliation glaucoma development in Saudi patients. Mol Vis 17:543-547.

Abu-Amero KK, Gonzalez AM, Larruga JM, Bosley TM and Cabrera VM (2007) Eurasian and African mitochondrial DNA influences in the Saudi Arabian population. BMC Evol Biol 7:32.

Abu-Amero KK, Hellani A, Gonzalez AM, Larruga JM, Cabrera VM and Underhill PA (2009) Saudi Arabian Y-Chromosome diversity and its relationship with nearby regions. BMC Genet 10:59.
Abu-Amero KK, Jaeger M, Plantinga T, Netea MG and Hassan HY (2013) Genetic Variation of TLR2 and TLR4 Among the Saudi Arabian Population: Insight into the Evolutionary Dynamics of the Arabian Peninsula. Genetic Testing and Molecular Biomarkers 17:166-169.

Abu-Amero KK, Larruga JM, Cabrera VM and Gonzalez AM (2008) Mitochondrial DNA structure in the Arabian Peninsula. BMC Evol Biol 8:45.

Al Omar S, Middleton D, Marshall E, Porter D, Xinarianos G, Raji O, Field JK and Christmas SE (2010) Associations between genes for killer immunoglobulin-like receptors and their ligands in patients with solid tumors. Hum Immunol 71:976-981.

Alsmadi O, Thareja G, Alkayal F, Rajagopalan R, John SE, Hebbar P, Behbehani K and Thanaraj TA (2013) Genetic Substructure of Kuwaiti Population Reveals Migration History. Plos One 8:e74913.

Augusto DG, Lobo-Alves SC, Melo MF, Pereira NF and PetzlErler ML (2012) Activating KIR and HLA Bw4 ligands are associated to decreased susceptibility to pemphigus foliaceus, an autoimmune blistering skin disease. PLoS One 7:e39991.

Brooks AG, Boyington JC and Sun PD (2000) Natural killer cell recognition of HLA class I molecules. Rev Immunogenet 2:433-448.

Cadenas AM, Zhivotovsky LA, Cavalli-Sforza LL, Underhill PA and Herrera RJ (2008) Y-chromosome diversity characterizes the Gulf of Oman. Eur J Hum Genet 16:374-386.

Caligiuri MA, Murray C, Levine H, Longtine JA and Ritz J (1989) Clonal evidence for the induction of NKH1 on activated human thymocytes. Functional changes associated with antigen expression. Eur J Immunol 19:1735-1739.

Carr WH, Pando MJ and Parham P (2005) KIR3DL1 polymorphisms that affect NK cell inhibition by HLA-Bw4 ligand. J Immunol 175:5222-5229.

Cella M, Longo A, Ferrara GB, Strominger JL and Colonna M (1994) NK3-specific natural killer cells are selectively inhibited by Bw4-positive HLA alleles with isoleucine 80 . J Exp Med 180:1235-1242.

Chavan VR, Chaudhari D, Ahir S, Ansari Z, Mehta P and Mania-Pramanik J (2014) Variations in KIR genes: a study in HIV-1 serodiscordant couples. Biomed Res Int 2014:891402.

Chewning JH, Gudme CN, Hsu KC, Selvakumar A and Dupont B (2007) KIR2DS1-positive NK cells mediate alloresponse against the C2 HLA-KIR ligand group in vitro. J Immunol 179:854-868.

Clarke KR (1993) Nonparametric Multivariate Analyses of Changes in Community Structure. Australian Journal of Ecology 18:117-143.

Cooper MA, Fehniger TA, Turner SC, Chen KS, Ghaheri BA, Ghayur T, Carson WE and Caligiuri MA (2001) Human natural killer cells: a unique innate immunoregulatory role for the CD56(bright) subset. Blood 97:3146-3151.

Denis L, Sivula J, Gourraud PA, Kerdudou N, Chout R, Ricard C, Moisan JP, Gagne K, Partanen J and Bignon JD (2005) Genetic diversity of KIR natural killer cell markers in populations from France, Guadeloupe, Finland, Senegal and Reunion. Tissue Antigens 66:267-276. 
Du Z, Gjertson DW, Reed EF and Rajalingam R (2007) Receptor-ligand analyses define minimal killer cell Ig-like receptor (KIR) in humans. Immunogenetics 59:1-15.

Faure M and Long EO (2002) KIR2DL4 (CD158d), an NK cellactivating receptor with inhibitory potential. J Immunol 168:6208-6214.

Foley B, De Santis D, Lathbury L, Christiansen F and Witt C (2008) KIR2DS1-mediated activation overrides NKG2Amediated inhibition in HLA-C C2-negative individuals. Int Immunol 20:555-563.

Gaafar A, Sheereen A, Iqneibi A, Mohamed G, Al Sulaiman A, Turpeinen H and Al Hussein K (2011) Killer cell immunoglobulin-like receptor gene diversity in the Saudi population. Mol Biol Rep 38:2603-2610.

Garcia-Leon JA, Pinto-Medel MJ, Garcia-Trujillo L, LopezGomez C, Oliver-Martos B, Prat-Arrojo I, Marin-Banasco C, Suardiaz-Garcia M, Maldonado-Sanchez R, FernandezFernandez O and Leyva-Fernandez L (2011) Killer cell immunoglobulin-like receptor genes in Spanish multiple sclerosis patients. Mol Immunol 48:1896-1902.

Gonzalez-Galarza FF, Takeshita LY, Santos EJ, Kempson F, Maia MH, Silva AL, Ghattaoraya GS, Alfirevic A, Jones AR and Middleton D (2014) Allele frequency net 2015 update: new features for HLA epitopes, KIR and disease and HLA adverse drug reaction associations. Nucleic Acids Res. 43:D784-788

Gumperz JE, Barber LD, Valiante NM, Percival L, Phillips JH, Lanier LL and Parham P (1997) Conserved and variable residues within the Bw4 motif of HLA-B make separable contributions to recognition by the NKB1 killer cell-inhibitory receptor. J Immunol 158:5237-5241.

Gumperz JE, Litwin V, Phillips JH, Lanier LL and Parham P (1995) The Bw4 public epitope of HLA-B molecules confers reactivity with natural killer cell clones that express NKB1, a putative HLA receptor. J Exp Med 181:1133-1144.

Hansasuta P, Dong T, Thananchai H, Weekes M, Willberg C, Aldemir H, Rowland-Jones S and Braud VM (2004) Recognition of HLA-A3 and HLA-A11 by KIR3DL2 is peptide-specific. Eur J Immunol 34:1673-1679.

Hiby SE, Ashrafian-Bonab M, Farrell L, Single RM, Balloux F, Carrington M, Moffett A and Ebrahimi Z (2010) Distribution of killer cell immunoglobulin-like receptors (KIR) and their HLA-C ligands in two Iranian populations. Immunogenetics 62:65-73.

Hollenbach JA, Meenagh A, Sleator C, Alaez C, Bengoche M, Canossi A, Contreras G, Creary L, Evseeva I, Gorodezky C, Hardie RA, Karlsen TH, Lie B, Luo M, Martinetti M, Navarette C, de Oliveira DC, Ozzella G, Pasi A, Pavlova E, Pinto S, Porto LC, Santos P, Slavcev A, Srinak D, Tavoularis S, Tonks S, Trachtenberg E, Vejbaesya S and Middleton D (2010) Report from the killer immunoglobulin-like receptor (KIR) anthropology component of the 15th International Histocompatibility Workshop: worldwide variation in the KIR loci and further evidence for the co-evolution of KIR and HLA. Tissue Antigens 76:9-17.

Hou YF, Zhang YC, Jiao YL, Wang LC, Li JF, Pan ZL, Yang QR, Sun HS and Zhao YR (2010) Disparate distribution of activating and inhibitory killer cell immunoglobulin-like receptor genes in patients with systemic lupus erythematosus. Lupus 19:20-26.
Ivarsson MA, Loh L, Marquardt N, Kekalainen E, Berglin L, Bjorkstrom NK, Westgren M, Nixon DF and Michaelsson J (2013) Differentiation and functional regulation of human fetal NK cells. J Clin Invest 123:3889-3901.

Jarduli LR, Sell AM, Reis PG, Sippert EA, Ayo CM, Mazini PS, Alves HV, Teixeira JJ and Visentainer JE (2013) Role of HLA, KIR, MICA, and cytokines genes in leprosy. Biomed Res Int 2013:989837.

Jiao YL, Zhang BC, You L, Li JF, Zhang J, Ma CY, Cui B, Wang LC, Chen ZJ and Zhao YR (2010) Polymorphisms of KIR gene and HLA-C alleles: possible association with susceptibility to HLA-B27-positive patients with ankylosing spondylitis. J Clin Immunol 30:840-844.

Kulkarni S, Martin MP and Carrington M (2008a) The Yin and Yang of HLA and KIR in human disease. Semin Immunol 20:343-352.

Kulkarni S, Single RM, Martin MP, Rajalingam R, Badwe R, Joshi N and Carrington M (2008b) Comparison of the rapidly evolving KIR locus in Parsis and natives of India. Immunogenetics 60:121-129.

Long EO, Colonna M and Lanier LL (1996) Inhibitory MHC class I receptors on NK and T cells: a standard nomenclature. Immunol Today 17:100.

Long EO and Rajagopalan S (2000) HLA class I recognition by killer cell Ig-like receptors. Semin Immunol 12:101-108.

Mandelboim O, Reyburn HT, Vales-Gomez M, Pazmany L, Colonna M, Borsellino G and Strominger JL (1996) Protection from lysis by natural killer cells of group 1 and 2 specificity is mediated by residue 80 in human histocompatibility leukocyte antigen $\mathrm{C}$ alleles and also occurs with empty major histocompatibility complex molecules. J Exp Med 184:913-922.

Marsh SG, Parham P, Dupont B, Geraghty DE, Trowsdale J, Middleton D, Vilches C, Carrington M, Witt C, Guethlein LA, Shilling H, Garcia CA, Hsu KC and Wain H (2003a) Killer-cell immunoglobulin-like receptor (KIR) nomenclature report, 2002. Hum Immunol 64:648-654.

Marsh SG, Parham P, Dupont B, Geraghty DE, Trowsdale J, Middleton D, Vilches C, Carrington M, Witt C, Guethlein LA, Shilling H, Garcia CA, Hsu KC and Wain H (2003b) Killer-cell immunoglobulin-like receptor (KIR) nomenclature report, 2002. Tissue Antigens 62:79-86.

Martin MP, Single RM, Wilson MJ, Trowsdale J and Carrington M (2008) KIR haplotypes defined by segregation analysis in 59 Centre d'Etude Polymorphisme Humain (CEPH) families. Immunogenetics 60:767-774.

Moesta AK, Norman PJ, Yawata M, Yawata N, Gleimer M and Parham P (2008) Synergistic polymorphism at two positions distal to the ligand-binding site makes KIR2DL2 a stronger receptor for HLA-C than KIR2DL3. J Immunol 180:39693979 .

Moretta A, Sivori S, Vitale M, Pende D, Morelli L, Augugliaro R, Bottino C and Moretta L (1995) Existence of both inhibitory (p58) and activatory (p50) receptors for HLA-C molecules in human natural killer cells. J Exp Med 182:875-884.

Moretta L, Montaldo E, Vacca P, Del Zotto G, Moretta F, Merli P, Locatelli F and Mingari MC (2014) Human natural killer cells: origin, receptors, function, and clinical applications. Int Arch Allergy Immunol 164:253-264.

Norman PJ, Stephens HA, Verity DH, Chandanayingyong D and Vaughan RW (2001) Distribution of natural killer cell im- 
munoglobulin-like receptor sequences in three ethnic groups. Immunogenetics 52:195-205.

O'Connor GM, Guinan KJ, Cunningham RT, Middleton D, Parham P and Gardiner CM (2007) Functional polymorphism of the KIR3DL1/S1 receptor on human NK cells. J Immunol 178:235-241.

Osman AE, Mubasher M, ElSheikh NE, AlHarthi H, Al Yami AS, Rajalingam R, Al-Dehaimi A, Middleton D and ElGhazali G (2014) Characterization of human killer immunoglobulinlike receptors (KIRs) among healthy Saudis. Hum Immunol 75:536-540.

Ozturk OG, Polat G and Atik U (2012) Diversity of killer cell immunoglobulin-like receptor genes in Southern Turkey. Mol Biol Rep 39:1989-1995.

Parham P (2005) Influence of KIR diversity on human immunity. Adv Exp Med Biol 560:47-50.

Parham P and Moffett A (2013) Variable NK cell receptors and their MHC class I ligands in immunity, reproduction and human evolution. Nat Rev Immunol 13:133-144.

Pedroza LS, Sauma MF, Vasconcelos JM, Takeshita LY, Ribeiro-Rodrigues EM, Sastre D, Barbosa CM, Chies JA, Veit TD, Lima CP, Oliveira LF, Henderson BL, Castro AP, Maia MH, Barbosa FB, Santos SE, Guerreiro JF, Sena L and Santos EJ (2011) Systemic lupus erythematosus: association with KIR and SLC11A1 polymorphisms, ethnic predisposition and influence in clinical manifestations at onset revealed by ancestry genetic markers in an urban Brazilian population. Lupus 20:265-273.

Petraglia MD (2003) The Lower Paleolithic of the Arabian Peninsula: Occupations, adaptations, and dispersals. Journal of World Prehistory 17:141-179.

Rajagopalan S and Long EO (2005) Understanding how combinations of HLA and KIR genes influence disease. J Exp Med 201:1025-1029.

Rayes R, Bazarbachi A, Khazen G, Sabbagh A, Zaatari G and Mahfouz R (2008) Natural killer cell immunoglobulin-like receptors (KIR) genotypes in two arab populations: will KIR become a genetic landmark between nations? Mol Biol Rep 35:225-229.

Rosa A and Brehem A (2011) African human mtDNA phylogeography at-a-glance. J Anthropol Sci 89:25-58.

Soares P, Alshamali F, Pereira JB, Fernandes V, Silva NM, Afonso C, Costa MD, Musilova E, Macaulay V, Richards MB, Cerny V and Pereira L (2012) The Expansion of
mtDNA Haplogroup L3 within and out of Africa. Mol Biol Evol 29:915-927.

Stewart CA, Laugier-Anfossi F, Vely F, Saulquin X, Riedmuller J, Tisserant A, Gauthier L, Romagne F, Ferracci G, Arosa FA, Moretta A, Sun PD, Ugolini S and Vivier E (2005) Recognition of peptide-MHC class I complexes by activating killer immunoglobulin-like receptors. Proc Natl Acad Sci U S A 102:13224-13229.

Tajik N, Shahsavar F, Mousavi T and Radjabzadeh MF (2009) Distribution of KIR genes in the Iranian population. Tissue Antigens 74:22-31.

Tajik N, Shahsavar F, Nasiri M and Radjabzadeh MF (2010) Compound KIR-HLA genotype analyses in the Iranian population by a novel PCR-SSP assay. Int $\mathrm{J}$ Immunogenet 37:159-168.

Torkar M, Norgate Z, Colonna M, Trowsdale J and Wilson MJ (1998) Isotypic variation of novel immunoglobulin-like transcript/killer cell inhibitory receptor loci in the leukocyte receptor complex. Eur J Immunol 28:3959-3967.

Uhrberg M, Parham P and Wernet P (2002) Definition of gene content for nine common group B haplotypes of the Caucasoid population: KIR haplotypes contain between seven and eleven KIR genes. Immunogenetics 54:221-229.

Vilches C, Castano J, Gomez-Lozano N and Estefania E (2007) Facilitation of KIR genotyping by a PCR-SSP method that amplifies short DNA fragments. Tissue Antigens 70:415422.

Vilches C and Parham P (2002) KIR: diverse, rapidly evolving receptors of innate and adaptive immunity. Annu Rev Immunol 20:217-251.

Wagtmann N, Rojo S, Eichler E, Mohrenweiser H and Long EO (1997) A new human gene complex encoding the killer cell inhibitory receptors and related monocyte/macrophage receptors. Curr Biol 7:615-618.

Williams F, Middleton D and Leheny W (2004) HLA-A and -B alleles, Cytokine polymorphisms and KIR gene frequencies in a population from Oman. Hum Immunol 65:1034-1038.

Wilson MJ, Torkar M, Haude A, Milne S, Jones T, Sheer D, Beck S and Trowsdale J (2000) Plasticity in the organization and sequences of human KIR/ILT gene families. Proc Natl Acad Sci U S A 97:4778-4783.

Associate Editor: Mara H. Hutz

License information: This is an open-access article distributed under the terms of the Creative Commons Attribution License (type CC-BY), which permits unrestricted use, distribution and reproduction in any medium, provided the original article is properly cited. 